Fourth International Conference on Sustainable Construction Materials and Technologies http://www.claisse.info/Proceedings.htm

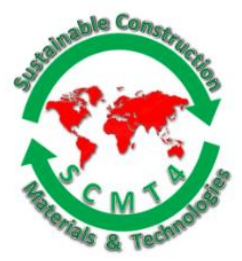

SCMT4

Las Vegas, USA, August 7-11, 2016

\title{
Environmental Friendly Concrete Using Waste Compact Discs as Fine Aggregate Replacement
}

\author{
Zainab Z. Ismail ${ }^{1}$, and Ali J. Jaeel ${ }^{2}$ \\ ${ }^{1}$ Department of Environmental Engineering, University of Baghdad, Baghdad, Iraq \\ Email: <zismail3@gatech.edu>, \\ ${ }^{2}$ Department of Civil Engineering, Wasit University, Wasit, Iraq \\ Email: <alijwied_2004@yahoo.com>.
}

\begin{abstract}
ABSTRUCT
This study aimed to investigate for the first time the utilization of waste compact discs (WCDs) granules in concrete mixtures to replace the fine aggregate by $5 \%, 10 \%, 15 \%$ and $20 \%$ by weight. The influence of partial replacement of the waste compact discs (WCDs) on the fundamental mechanical and strength properties of the WCDs-modified concrete mixtures were investigated. The properties included workability, bulk density, compressive strength, flexural strength, and split tensile strength. Compared to the control or reference concrete, results revealed that using waste compact discs in concrete mixes mixture improved the workability and the dry density, as well as reducing the compressive strength of concrete containing $10 \%$ and $15 \%$ of waste by $15 \%$ to $20 \%$, respectively after 28 days curing. Also, the split tensile strength values of WCDs-modified concrete mixtures were increased by $10 \%$ and $12 \%$ when the ratio of waste compact discs were $10 \%$ and $15 \%$, respectively after 28 days curing. On the other hand, the leaching test revealed that none of the WCDs constituents was detected in the leachant after 180 days. The findings of this work would form basic information for recycling the waste compact discs (WCDs) in concrete mixes and indicate a potential alternative for diminution the adverse effects on the environment posed by this type of hazardous waste material.
\end{abstract}

\section{INTRODUCTION}

Electronic waste and its accessories are one of the fastest-growing pollution problems worldwide given the presence if a variety of toxic substances which can contaminate the environment and threaten human health, if disposal protocols are not meticulously managed [Kiddee et al. 2013]. Waste compact discs, especially those related to computer software are often disposed of with other waste electrical and electronic equipment (WEEE) fractions, if they don't end up in the wastes from households or offices. The structure and composition of CDs is such that when these end up on landfills or in waste incinerators not much harm will be done [Zevenhoven and Saeed 2003]. Billions of optical discs have been manufactured and distributed worldwide. As electronic storage media evolve, these discs are becoming obsolete. Most unwanted household discs end up in the landfills or incinerators. Recycling options for waste discs exist, but public awareness and participation are low [Biehn, 2008]. A compact disc is made up of a polycarbonate disc body ( $95 \%$ by volume), with the dye and reflective layers on the surface. The dye layer contains organic dyes like metal azo to store data while the reflective layer is made up of metals like aluminum to reflect the laser. Worldwide, CDs production is increasing with around $10 \%$ per year. Of these, almost $25 \%$ can be considered to be waste immediately, being misprints or distributed with commercial material, never to be 
used. At a weight of $20 \mathrm{~g}$ per CD this implies a waste stream of several 100000 tons per year worldwide. Every year, huge amounts of compact discs are discarded all over the world. The non-biodegradable polycarbonate, heavy metals and harmful dyes of the discs lead to serious pollution problems. Few countries have started to recycle compact discs and the current process is not efficient and has many drawbacks, involves the use of toxic chemicals and pays no attention to the treatment of dyes. Alavi Nikje and Askarzadeh [2013] studied the chemical recycling of waste CDs into bisphenol A (BPA) - using a ternary solvent system: glycerin, sorbitol, water under conventional heating method. Rajarao et al. [2014] reported a novel approach to synthesis silicon carbide $(\mathrm{SiC})$ nanoparticles by using electronic waste compact discs (CDs) char as a carbon source. Zander et al. [2015] investigated new methods to reprocess the excess of plastics in the waste stream including polycarbonate from compact discs (CDs) into nano-fibers as fine as ca. $100 \mathrm{~nm}$ in diameter using the electro-spinning technique. Based on the available methods for recycling of waste compact discs, a modified and more environmentally friendly process could be suggested for recycling of compact discs such as dumping in concrete mixtures.

On the other hand, concrete is the most widely used man made construction material, it has the largest production of all man-made materials with an annual global production of about 3.8 billion $\mathrm{m}^{3}$ which is approximately equal to $1 \mathrm{~m}^{3}$ for every person on earth [Ismail and Al-Hashmi 2011]. Concrete plays a significant role in this era of modernization. Seeking aggregates for concrete and disposing of waste materials from various commodities is the present concern. Today sustainability has got top priority in construction industry. Numerous research papers have been published on solid waste-modified concrete mixes. Different types of solid waste materials including but not limited to fly ash, waste glass, waste plastic, waste copper slag, and rubber have been used as aggregate in concrete mixes. Their mechanical properties and quality have been examined and compared to the normal concrete mixes [Neville 1997; Ismail and Al-Hashmi 2009; Al-Jabri et al. 2009; Du and Tan 2013; Xue et al. 2013].

However, to our knowledge yet only one research paper about the addition of waste CDs shreds in concrete has been reported by Tang et al. [2008]. However, no research work has been reported concerning the replacement of fine aggregate by granules of waste CDs. This research paper presents for the first time the experimental investigation carried out to study the effect of waste compact discs granules on the fundamental mechanical properties of concrete when used to partially replace the fine aggregates in concrete mixtures.

\section{MATERIALS AND METHODS}

\section{Materials}

Type I Portland cement was used in all types of concrete mixtures. The chemical and physical properties of the cement are presented in Tables 1 and 2, respectively. The chemical analysis of cement was carried out according to ASTM C114. The fine aggregate was natural sand of $4.75 \mathrm{~mm}$ maximum size supplied from the Al-Ukaider area in Iraq. Its grading conformed to ASTM C136. The properties and gradation of sand are shown in Tables 3 and 4, respectively. Natural crushed coarse aggregate of maximum size 20 $\mathrm{mm}$ and bulk density of $1550 \mathrm{~kg} / \mathrm{m}^{3}$ was supplied from the Al-Nibaey region in Iraq.

Waste compact discs were collected from several offices and houses. After collection of the compact discs, they were crushed down to the size of fine aggregates and directly used with different percentages to partially replace the fine aggregate in concrete. The density of crushed waste compact discs granules was $1120 \mathrm{~kg} / \mathrm{m}^{3}$.

\section{Concrete mixture proportioning}


Reference concrete mixtures: This mixture denoted as (WCD0) consisted of $739 \mathrm{~kg} / \mathrm{m}^{3}$ sand, $928 \mathrm{~kg} / \mathrm{m}^{3}$ gravel, $415 \mathrm{~kg} / \mathrm{m}^{3}$ cement and water: cement (W/C) ratio of 0.55 . This conventional concrete mixture was free of waste compact discs granules.

Waste compact discs-modified concrete mixtures: Four types of WCDs-modified concrete were prepared by the addition of waste compact disc (WCDs) granules to replace the fine aggregate by $5 \%$, $10 \%, 15 \%$ and $20 \%$ by weight and these mixtures were denoted as WCD1, WCD2, WCD3, and WCD4, respectively. Table 5 presents the details of the WCDs-modified concrete mixtures.

Table 1. Chemical Composition of Cement

\begin{tabular}{|c|c|c|}
\hline Compounds & Abbreviation & $\%$ Weight \\
\hline Lime & $\mathrm{CaO}$ & 58.80 \\
\hline Silica & $\mathrm{SiO}_{2}$ & 22.50 \\
\hline Alumina & $\mathrm{Al}_{2} \mathrm{O}_{2}$ & 4.57 \\
\hline Iron oxide & $\mathrm{Fe}_{2} \mathrm{O}_{3}$ & 5.89 \\
\hline Sulfite & $\mathrm{SO}_{3}$ & 2.31 \\
\hline Magnesia & $\mathrm{MgO}$ & 4.90 \\
\hline Loss of ignition & L.O.I & 3.29 \\
\hline Lime saturation factor & L.S.F & 0.81 \\
\hline Insoluble residue & $\mathrm{I} . \mathrm{R}$ & 1.39 \\
\hline Tricalcium silicate & $\mathrm{C}_{3} \mathrm{~S}$ & 60.50 \\
\hline Dicalcium silicate & $\mathrm{C}_{2} \mathrm{~S}$ & 10.85 \\
\hline Tricalcium aluminate & $\mathrm{C}_{3} \mathrm{~A}$ & 8.94 \\
\hline Tetra calcium aluminoferrite & $\mathrm{C}_{4} \mathrm{AF}$ & 3.63 \\
\hline
\end{tabular}

Table 2. Physical Properties of Cement

\begin{tabular}{|c|c|c|c|}
\hline \multicolumn{2}{|c|}{ Item } & Values & Test method \\
\hline \multicolumn{2}{|c|}{ Fineness } & 277 & ASTM C204 \\
\hline Safety - Elongation & 0.17 & ASTM C191 \\
\hline \multirow{2}{*}{ Compressive strength (Mpa) } & 3 days & 16.9 & ASTM C191 \\
\cline { 2 - 4 } & 7 days & 26.1 & ASTM C151 \\
\hline \multirow{2}{*}{ Setting Time (Min) } & Initial & 78.0 & ASTM C109 \\
\cline { 2 - 4 } & Final & 278 & ASTM C109 \\
\hline
\end{tabular}

Table 3. Properties of Sand

\begin{tabular}{|c|c|}
\hline Properties & Limit \\
\hline Sulfate $(\%)$ & 0.80 \\
\hline Finesse modulus & 2.31 \\
\hline Absorption $(\%)$ & 2.90 \\
\hline Max size $(\mathrm{mm})$ & 4.75 \\
\hline Density $\left(\mathrm{kg} / \mathrm{m}^{3}\right)$ & 1700 \\
\hline Specific gravity & 2.59 \\
\hline
\end{tabular}


Table 4. Gradation of Fine Aggregate

\begin{tabular}{|c|c|}
\hline $\begin{array}{c}\text { Sieve size } \\
(\mathrm{mm})\end{array}$ & Accumulated percentage passing \\
\hline 4.75 & 91.50 \\
\hline 2.36 & 88.25 \\
\hline 1.18 & 82.60 \\
\hline 0.6 & 66.75 \\
\hline 0.3 & 21.20 \\
\hline 0.15 & 1.30 \\
\hline
\end{tabular}

Table 5. Mix Proportions of WCD Modified Concrete

\begin{tabular}{|c|c|c|c|c|c|c|}
\hline $\begin{array}{c}\text { Concrete } \\
\text { Mixture }\end{array}$ & $\begin{array}{c}\text { Cement } \\
\left(\mathrm{kg} / \mathrm{m}^{3}\right)\end{array}$ & $\begin{array}{c}\text { Gravel } \\
\left(\mathrm{kg} / \mathrm{m}^{3}\right)\end{array}$ & $\begin{array}{c}\text { Sand } \\
\left(\mathrm{kg} / \mathrm{m}^{3}\right)\end{array}$ & $\begin{array}{c}\text { WCDs } \\
(\%)\end{array}$ & $\begin{array}{c}\text { WCDs } \\
\left(\mathrm{kg} / \mathrm{m}^{3}\right)\end{array}$ & $\begin{array}{c}\text { W/C } \\
\text { Ratio }\end{array}$ \\
\hline CDW0 & 415 & 928 & 739 & 0 & 0 & 0.55 \\
\hline CDW1 & 415 & 928 & 702.05 & 5 & 36.95 & 0.55 \\
\hline CDW2 & 415 & 928 & 665.10 & 10 & 73.90 & 0.55 \\
\hline CDW3 & 415 & 928 & 628.30 & 15 & 110.70 & 0.55 \\
\hline CDW4 & 415 & 928 & 591.20 & 20 & 147.80 & 0.55 \\
\hline
\end{tabular}

Specimen and tests. Concrete cubes of size $150 \times 150 \times 150 \mathrm{~mm}$ were molded for compressive strength, and fresh dry density tests. Concrete prisms of size $70 \times 70 \times 38 \mathrm{~mm}$ were cast for flexural and toughness strength tests. Casting, compaction and curing were accomplished according to B.S.1881, parts 7 and 6 . Slump test was fulfilled according to B.S.1881, part 2. Dry densities were measured according to B.S.1881, part 5 for the cubes taken from curing water basin just prior to compression strength test. The dry density represents the mean of dry density of 4 cubes of each curing age. The compression strength test was accomplished using The Forney machine. The concrete cubes were prepared according to B.S.1881, part 7. The cubes were tested immediately after taken out of water while they were still wet. The average of compression strength of 4 cubes was recorded for each testing age. For the flexural strength test, prisms were prepared according to ASTM C192. A $10 \mathrm{KN}$ proving ring capacity and $0.01 \mathrm{~mm}$ dial gage precision was used for those tests. The flexural strength was carried out according to ASTM C293. The toughness indices were implemented according to ASTM C1018. Split tensile strength tests were carried out as specified in BS1881- 117. Cylindrical concrete specimens of size $150 \mathrm{~mm}$ diameter $\times 200 \mathrm{~mm}$ long were molded and stored in water for 28 days before testing for tensile splitting strength. The automatic universal testing machine was used for the test. The samples were prepared in triplicate for each mix proportion used. All mixtures were cured for 3, 7, 14, and 28 days.

\section{RESULTS AND TESTS}

Workability (Slump test). The effect of the replacement of fine aggregates by WCDs on the workability of the concrete mixtures is presented in figure 3. Results revealed that the slump values prone to decrease sharply with increasing the WCDs ratio. The reduction can be attributed to the fact that some particles of WCDs are angular and others have non-uniform shapes which may results in less fluidity. In spite of the slump reduction, the WCDs-modified concrete mixtures have easy workability and are suitable for use in many applications based on the fact that Workability has a broad range from very low (at slump $=0-25$ $\mathrm{mm}$ ) applied for vibrated concrete in roads or other large sections, to high workability (at slump $=100-180$ $\mathrm{mm}$ ) applied for sections with congested reinforcement [Koehler and Fowler 2003]. Also, Naik et al. [1996] reported that concrete products with plastic material have easy workability. 


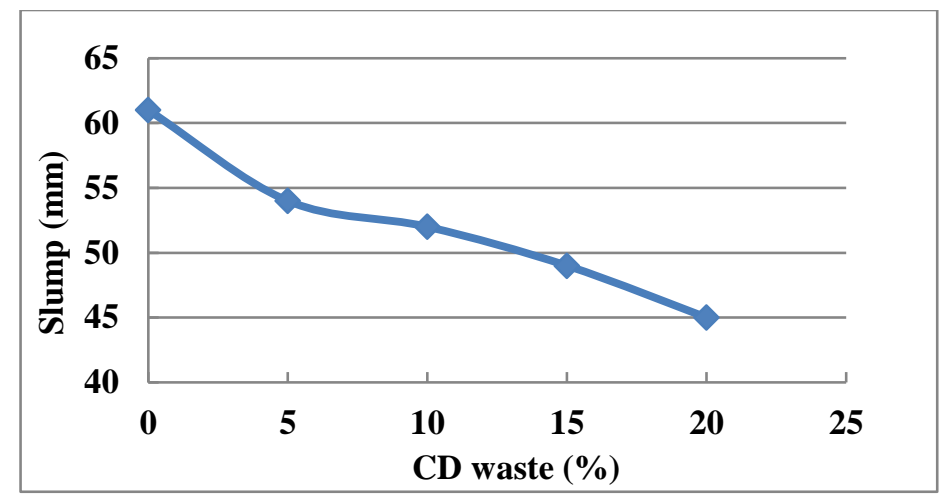

Figure 1. Slump Tests Profile for WCDs-Modified Concrete

Dry density test. The dry density tests for waste concrete mixtures WCD1, WCD2, WCD3, and WCD4 are shown in Fig.2. The dry densities at each curing age tend to decrease with increasing the WCDs ratio in each concrete mixture, but the dry densities tend to increase with time for each concrete mixture at all curing ages. The use of waste compact discs reduced the dry densities of all mixtures with increasing the waste ratio because the density of WCDs is lower than that of sand by about $45 \%$.

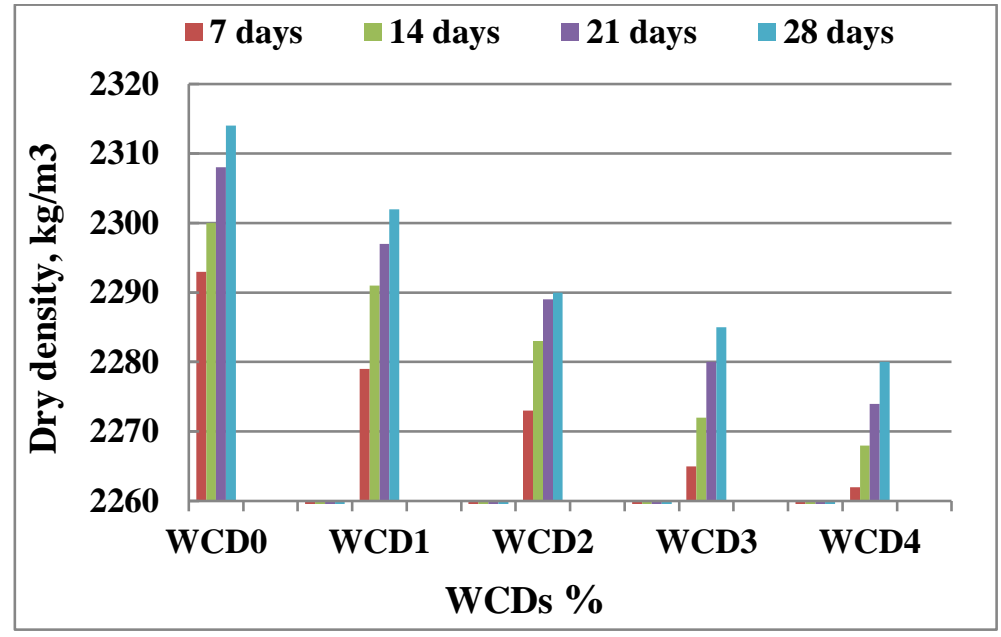

Figure 2. Dry Densities of WCDs-Modified Concrete at Different Curing Ages

Compressive, flexural and tensile strength tests. The results of compressive, flexural and tensile strengths tests for the WCDs-modified concrete mixtures are illustrated in Figs. 3, 4, and 5, respectively. By increasing the waste ratio, the results show a tendency for strength values for the WCDs-modified concrete mixtures to increase above the plain mixtures at each curing age for the concrete mixtures WCD1, WCD2, and WCD3. This trend can be attributed to the bonding forces between the plastic particles and concrete mixture due to the roughness of the crushed WCDs. On the other hand the compressive, flexural, and tensile strengths of the WCD4 mixture decreased by 5\% at age 28 days. This decrement can be attributed to hydrophobic nature of plastic material as the absorption of water by plastic is very low which may limit the hydration of cement. Accordingly, the high ratio of plastic may lead to increase the ratio of non-absorbed water (fluidity of concrete) and the subsequent decrease of the compressive strength values for modified concrete mixes containing high ratios of WCDs. However all of the compressive strength values are higher than the minimum compressive strength required for structural concrete which is 17.24 Mpa. Similar behaviors as for compressive strength were observed for the flexural and tensile strengths. 


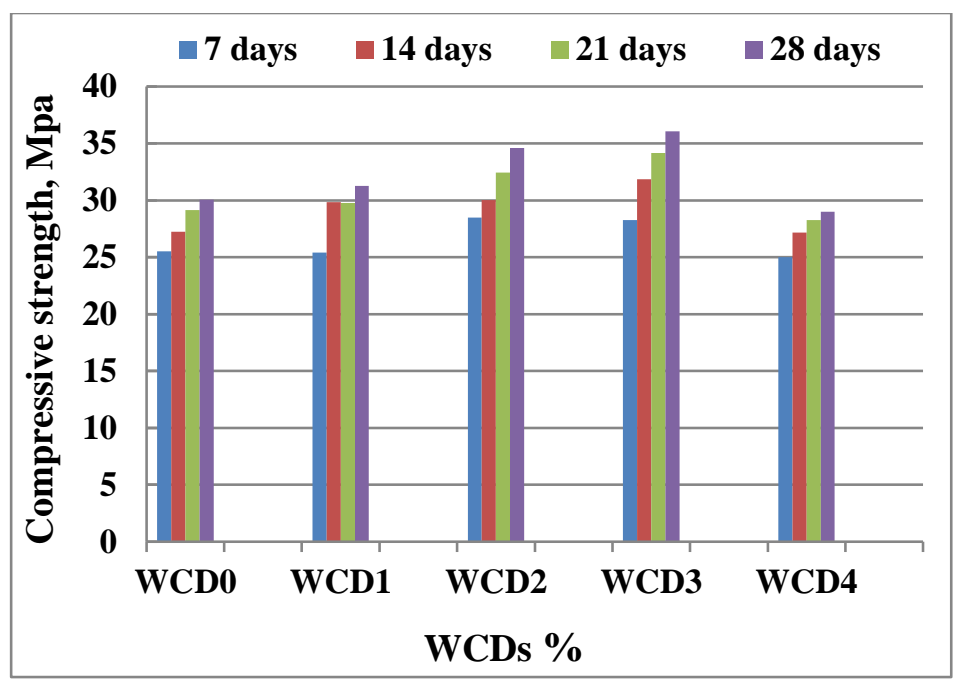

Figure 3. Compressive Strength of WCDs-Modified Concrete at Different Curing Ages

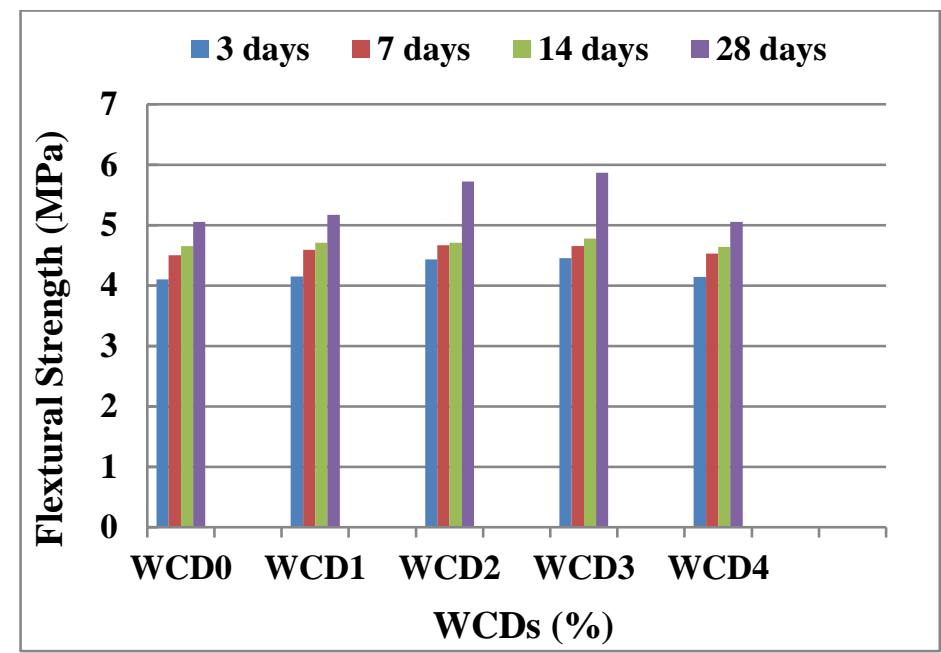

Figure 4. Flexural Strength of WCDs-Modified Concrete at Different Curing Ages

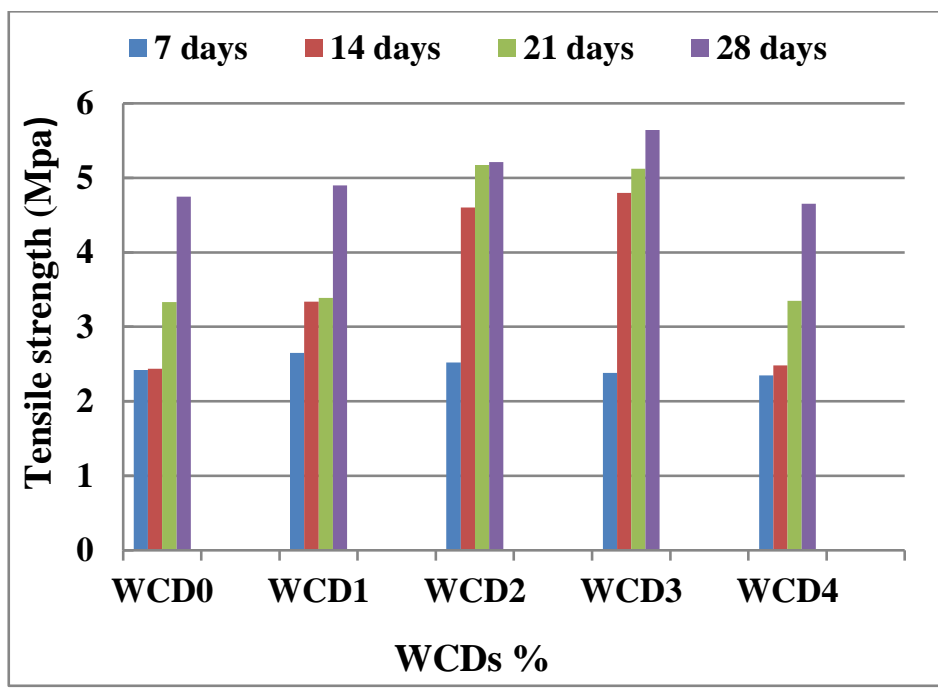

Figure 5. Tensile Strength of WCDs-Modified Concrete at Different Curing Ages 
Leaching test. Chemical characterization for metal leaching behavior from WCDs-modified concrete mixes was made after 28 and 180 days of curing according to the standard test method for leaching of trace elements from hardened concrete (JSCE G575-2005). Target trace elements were Aluminum (Al), Cadmium (Cd), Nickel (Ni), Copper ( $\mathrm{Cu})$, Cobalt $(\mathrm{Co})$, Chromium $(\mathrm{Cr})$, and Lead $(\mathrm{Pb})$. A tank leaching method was performed to carry out leaching test from hardened concrete where the leachant was double distilled water. Results of the tests indicated the absence of the target elements in the leachant.

Also, tests of chemical oxygen demand (COD), turbidity, total suspended solids (TSS) and total dissolved solids (TDS) and were carried out for the leachant. Results of the leaching test revealed that none of these constituents were detected in the leachant. The disappearance of these constituents in the leachant could be attributed to the assumption that a potential retention of the polymeric particulates of WCD occurred within the structure of WCDs-modified concrete. The results of the leaching test implied that using CDWs is non-hazardous for concrete mixes and could meet the requirements of clean construction products.

\section{CONCLUSION}

The main conclusions that can be drawn from this study are:

- Compact disc waste can be used successfully to replace conventional fine aggregate in concrete without any long-term detrimental effects and with acceptable strength development properties.

- The slump values of waste disc concrete mixtures showed a tendency to decrease below the slump of the reference concrete mixture. In spite of this decline in the slump values of WCDs-modified concrete mixtures, they were easy to work based on the consideration that workability has a broad range from very low to high workability for different applications.

- The dry density values of WCDs-modified concrete mixtures at each curing age tend to decrease below the dry density value of the reference concrete mixture. However, they were averaged to the dry density value of the reference concrete mixtures. At 28 days curing age, the lowest dry density $(2280 \mathrm{~kg} / \mathrm{m} 3)$ exceeds the range of the dry density of structural lightweight concrete.

- The compressive, flexural and tensile strength values of all WCDs-modified concrete mixtures tend to increase above the values for the reference concrete mixtures with increasing the waste ratio at all curing ages. This may be attributed to the increase in the adhesive strength between the surface of the crushed waste and cement paste.

- Leaching test revealed that using WCDs to partially replace aggregate in concrete mixtures is a nonhazardous approach and could meet the requirements of clean construction products.

\section{REFERENCES}

Al-Jabri, K.S., Hisada, M., Al-Oraimi, S.K., Al-Saidy, A.H. (2009). "Copper slag as sand replacement for high performance concrete." Cement and Concrete Composites, 31, 483-8.

Alavi Nikje, M.M., Askarzadeh, M. (2013). "Chemical recycling of polycarbonate wastes into bisphenol A by using green solvent composition.” Polimery/polymers, 58, 292-294.

ASTM C 109. "Standard test method for compressive strength of hydraulic cement." ASTM International, West Conshohocken, PA.

ASTM C 114. "Standard chemical analysis of hydraulic cement." ASTM International, West Conshohocken, PA. 
ASTM C 136. "Standard test method for sieve analysis of fine and coarse aggregates." ASTM International, West Conshohocken, PA.

ASTM C 151." Standard test method for autoclave expansion of hydraulic cement. ASTM International, West Conshohocken, PA.

ASTM C 293. "Standard test method for flexural strength of concrete using simple beam with center-point loading." ASTM International, West Conshohocken, PA.

ASTM C 1018. "Standard test method for flexural toughness and first crack strength of fiber-reinforced concrete using bean with third-point loading." ASTM International, West Conshohocken, PA.

ASTM C 191. "Standard test method for time of setting of hydraulic cement by vicat needle." ASTM International, West Conshohocken, PA.

ASTM C 192. "Standard practice for making and curing concrete test specimens in laboratory." ASTM International, West Conshohocken, PA.

ASTM C 204." Standard test method for fineness of hydraulic cement by air permeability apparatus." ASTM International, West Conshohocken, PA.

ASTM C 618. "Standard specification for coal fly ash and raw or calcined natural pozzolan for use as a mineral admixture in concrete. Cement; Lime; Gypsum." ASTM International, West Conshohocken, PA.

Batayneh, M., Marie, I., Asi, I. (2007). "Use of selected waste materials in concrete mixes." Waste Management, 27(12), 1870-1876.

Biehn, A.w. (2008). "Compact discard: Finding environmentally responsible ways to manage discarded household CDs and DVDs." Master Thesis, submitted to University of Pennsylvania, Department of earth and environmental science.

B.S.1881. "Methods of testing concrete." BSI, London.

B.S.1881 - 117. "Testing concrete - method for determination of tensile splitting strength." BSI, London.

Du, H., Tan, K.H. (2013). "Use of waste glass as sand in mortar: Part II-Alkali-silica reaction and mitigation methods." Cement and Concrete Composites, 35,118-26.

Ismail, Z.Z., Al-Hashmi, E.A. (2009). "Recycling of waste glass as a partial replacement for fine aggregate in concrete." Waste Management, 29, 655-9.

Ismail, Z.Z., Al-Hashmi, E.A. (2011). "Assessing the recycling potential of industrial wastewater to replace fresh water in concrete mixes: application of polyvinyl acetate resin wastewater." Journal of Cleaner Production, 19, 197-203.

Kiddee, P., Naidua, R., Wong, M. H. (2013). "Electronic waste management approaches: An overview." Waste Management, 33, 1237-1250.

Koehler, E.P., Fowler, D.W. (2003). "ICAR 105: measuring the workability of high fines concrete for aggregate." International Center for Aggregate Research, University of Texas at Austin.

Mehta, P. K. (2002). "Greening of the concrete industry for sustainable development." Concrete International, 24, 23-27.

Naik, T.R., Singh, S.S., Huber, C.O., Brodersen, B.S. (1996). "Uso di scarti plastici post-utilizzati nel cemento a base di materiali composite." Cement and Concrete Composites, 26, 1489-1492.

Neville, A. M. (1997). "Properties of concrete," 4th Ed, Addison Wesley Longman, London. 
Rajarao, R., Ferreira, R., Sadi, S.H.F., Khanna, R., Sahajwalla, V. (2014). "Synthesis of silicon carbide nanoparticles by using electronic waste as a carbon source." Materials Letters, 120, 65-68.

Shen, W., Shan, L., Zhang, T., Ma, H., Cai, Z., Shi, H. (2013). "Investigation on polymer-rubber aggregate modified porous concrete." Construction and Building Materials, 38, 667-74.

Xue, J., Shinozuka, M. (2013). "Rubberized concrete: A green structural material with enhanced energydissipation capability." Construction and Building Materials, 42,196-204.

Zander, N.E., Sweetser, D., Cole, D.P., Gillan, M. (2015). "Formation of Nanofibers from Pure and Mixed Waste Streams Using Electrospinning.” Industrial \& Engineering Chemistry Research, 54, 9057-9063

Zevenhoven, R., Saeed, L. (2003). "Automotive shredder residue (ASR) and compact disc (CD) waste: Options for recovery of materials and energy." Report by Helsinki University of Technology Department of Mechanical Engineering. 